medullary tumours are said rarely to produce pain as compared to the frequency with which extramedullary tumours present with pain as an early symptom. The reason for this being that the nerve roots are not involved so frequently in the case of intramedullary tumours. Sensory and motor disturbances are a more common mode of presentation and are steadily progressive until a definite transverse cord lesion with a sensory level is produced. The upper sensory level in intramedullary tumours is less distinct than in extramedullary form. Loss of sphincter control below the level of the lesion occurs early in the intramedullary type (Rasmussen et al., 1940).

The prognosis of an intramedullary oligodendroglioma is probably better than in other forms of intramedullary spinal tumours since it is so slow-growing. An intramedullary tumour discovered at operation need not be considered inoperable (Woods \& Pimenta, 1944). It is often impossible to differentiate extramedullary from intramedullary tumours prior to operation.

\section{Summary}

A case of a primary spinal oligodendroglioma is reported. This is a rare tumour and in our search of literature we found only eleven previously reported cases. The patient presented as a case of attempted suicide.

\section{Acknowledgments}

We should like to express our thanks to Dr J. D. Williams and $\mathrm{Mr}$ G. B. Northcroft for allowing us to report this case.

\section{References}

Bailey, P. \& Cushing, H. (1926) A Classification of the Tumours of the Glioma Group on a Histogenetic Basis with a Correlated Study of Prognosis, p. 175. Lippincott, Philadelphia.

Bailey, P. \& Hillier, G. (1924) The interstitial tissues of the central nervous system; a review. J. nerv. ment. Dis. 59, 337.

Earnest, F., Kernohan, J.W. \& Craig, W.McK. (1950) Oligodendrogliomas-A review of 200 cases. Arch. Neurol. Psychiat. (Chic.), 63, 964.

Enestrom, S. \& Grontoft, O. (1957) Oligodendroglioma of the spinal cord. Acta path. microbiol. scand. 11, 396.

Kernohan, J.W., Woltman, H.W. \& Adson, A.W. (1931) Intramedullary tumours of the spinal cord. Arch. Neurol. Psychiat. (Chic.), 25, 679.

Kernohan, J.W., Woltman, H.W. \& Adson, A.W. (1933) Gliomas arising from the region of the cauda equina; clinical, surgical and histologic considerations. Arch. Neurol. Psychiat. (Chic.), 29, 287.

Love, J.G. \& Rivers, M.H. (1962) 31 year cure following removal of intramedullary glioma of cervical portion of spinal cord. J. Neurosurg. 19, 906.

OlJENick, I. (1936) Intramedullaire Gezwellen. Ned. T. Geneesk. 80, 1335.

Rasmussen T.B., Kernohan, J.W. \& Adson, A.W. (1940) Pathologic classification with surgical consideration of intraspinal tumours. Ann. Surg. 3, 513.

Russell, J.R. \& BuCY, P.C. (1949) Oligodendroglioma of the spinal cord. J. Neurosurg. 6, 433.

Strang, R.R. \& Nordenstam, H. (1961) Intracerebral oligodendroglioma with metastatic involvement of the caude equina. J. Neurosurg. 18, 683.

Woods, W.W. \& Pimenta, A.M. (1944) Intramedullary lesions of the spinal cord-Study of 68 consecutive cases. Arch. Neurol. Psychiat. (Chic.), 52, 383.

\title{
Phenacetin nephropathy in a patient with an ileostomy
}

\author{
N. H. DYER* \\ M.A., M.B., M.R.C.P. \\ Medical Registrar
}

\author{
F. I. LEE $\dagger$ \\ M.B., M.R.C.P. \\ Senior Medical Registrar
}

The London Hospital, London, E.1

\begin{abstract}
An ASSOCIATION between excessive ingestion of analgesic compounds containing phenacetin and renal damage is established (Spühler \& Zollinger, 1953). Moeschlin (1958) estimated that there were 20,000 analgesic abusers in Switzerland and in Denmark $29 \%$ of hospital in-patients take phenacetin each day (Larsen \& Moller, 1959). In Finland, $20 \%$ of in-patients and $10 \%$ of factory

\footnotetext{
* Present post: Research Registrar, St Bartholomew's Hospital, London, E.C.1.

†Present post: Physician, Victoria Hospital, Blackpool, Lancs.
}

workers ingest analgesic compounds daily (Kasanen, Forsström \& Salmi, 1962). The extent of the problem in the United Kingdom has probably been underestimated. Prescott (1966) found that abuse of analgesics was common in north-east Scotland, and that it was the cause of considerable morbidity and mortality from renal disease. He also commented on some unusual reasons for this abuse. We report here a patient who took an analgesic compound for the constipating effect of its codeine content, and in whom phenacetin nephropathy developed. 


\section{Case report}

The patient was a man aged 40 years. At the age of 16 he developed ulcerative colitis which slowly worsened with intermittent attacks. At the age of 26 a total colectomy with spout ileostomy was performed at another hospital. The rectum was not removed. At this time his blood pressure was $175 / 80$, his blood urea $29 \mathrm{mg} / 100 \mathrm{ml}$, and a mid-stream specimen of urine contained no pus cells and was sterile on culture. The ileostomy motions were lose at first but no measures to control them were needed. After 2 years the ileostomy was closed and an ileo-rectal anastomosis constructed. The disease recurred and an ileostomy was refashioned through the scar tissue of the old operation. Faeces tended to leak and were much more troublesome than previously. He found that codeine made the ileostomy easier to manage, and he took three to five compound codeine tablets daily. He bought his supply from his chemist as he did not wish to trouble his family doctor for a prescription for codeine phosphate. He suffered episodes of suprapubic pain, dysuria and frequency of micturition approximately twice a year. The symptoms improved with antibiotic therapy but no bacteriological studies were performed. There was no haematuria or renal colic and no necrotic papillae were voided. At the age of 38 he developed nocturia, once per night, without diurnal frequency. Three months before admission he suffered the first of three episodes of loin pain, malaise and dysuria. Albuminuria was found during a routine medical examination and he was referred to hospital. He admitted to a little mucus discharge from his rectal stump. On examination he appeared healthy with no signs of uraemia, anaemia or methaemoglobinaemia. His blood pressure varied from $120 / 80$ to $170 / 105$. The liver and spleen were just palpable. Apart from the operation scars there were no other abnormal findings.

The urine contained $2 \cdot 2 \mathrm{~g}$ protein $/ 24 \mathrm{hr}$. The specific gravity varied between 1.003 and 1.008 . The $\mathrm{pH}$ was 6 . The deposit contained a few epithelial cells and hyaline casts and, on two out of six occasions, a few leucocytes. Culture was repeatedly sterile, and a colony count revealed less than $10^{4}$ organisms $/ \mathrm{mm}^{3}$.

There was no evidence of haemolysis or methaemoglobinaemia. Blood film was normal and no Heinz bodies were seen. Blood urea varied from 67 to $120 \mathrm{mg} / 100 \mathrm{ml}$, and plasma creatinine from $4 \cdot 2$ to $5 \cdot 7 \mathrm{mg} / 100 \mathrm{ml}$. Serum bicarbonate was $11 \mathrm{mEq} / 1$ and the other electrolytes were normal. Creatinine clearance was $24 \mathrm{ml} / \mathrm{min}$, and maximum urinary urea concentration $7 \cdot 5 \mathrm{~g} / 1$. An infusion intravenous pyelogram showed that both kidneys were reduced in size with irregular outlines and an increase in peripelvic fat. The pelvicalyceal systems were not well outlined. Renal biopsy included twelve glomeruli, all of which were shrunken and fibrotic. Periglomerular fibrosis was absent. There was diffuse interstitial fibrosis and tubular atrophy with focal lymphocytic infiltration. The vessels showed mild hypertensive changes. A separate fragment of medulla contained an extensive infarct of a renal papilla, which was diffusely calcified. Liver biopsy revealed an increased amount of lipofuscin, but was otherwise normal. Ulcerative proctitis of the rectal stump was found on sigmoidoscopy, but a barium enema revealed no adverse features.

He felt better on withdrawal of the phenacetin and commencement of oral sodium bicarbonate, but there was no immediate improvement in renal function.

\section{Discussion}

Compound codeine tablets contain $250 \mathrm{mg}$ of aspirin, $250 \mathrm{mg}$ of phenacetin and $8 \mathrm{mg}$ of codeine. His phenacetin intake was therefore approximately $1 \mathrm{~g}$ daily for 10 years, giving a total consumption of more than $3.5 \mathrm{~kg}$. This is sufficient to reduce renal function and cause renal damage in most cases (Larsen \& Moller, 1959; Burry, de Jersey \& Weedon, 1966). The renal biopsy appearances of the healed papillary infarct are almost pathognomonic of phenacetin nephropathy. The severe cortical damage is not against the diagnosis especially as it is out of proportion to the vascular damage. The hepatic lipofuscin deposition is further evidence of a tissue response to phenacetin (Abrahams et al., 1964 ; Rubinstein et al., 1964). Renal lesions have been described in ulcerative colitis by Jensen, Baggenstoss \& Bargen (1950), but none of their cases developed papillary necrosis or chronic pyelonephritis.

Nordenfelt \& Ringertz (1961), Grimlund (1963) and Prescott (1966) noted that most of their cases commenced the analgesic habit on the advice of other laymen and unknown to their doctors. Our patient did not wish to trouble his doctor and could easily obtain compound codeine tablets from his chemist. In most countries the popular analgesics do not contain codeine, but Prescott (1966) found that codeine-phenacetin combinations were favoured in twentv-two of his thirty-six cases and had been taken in ten of the eleven previously reported cases of analgesic nephropathy in the United Kingdom.

Reasons for analgesic abuse vary. Some patients have chronic painful organic disease (Clausen \& Pederson, 1961) but these are in a minority 
(Nordenfelt \& Ringertz, 1961; Kielholz, 1957; Gsell, Kielholz \& Hegg, 1961). Kielholz (1957) suggested that in many cases the drug ingestion was a symptom of psychosomatic disorders and that abuse progressed to addiction. This view is supported by many authors (Dawborn et al., 1966 ; Reynolds \& Edmonson, 1963; Harvald, 1963). However, Prescott (1966) felt that many of his cases could not be classed as mentally abnormal, although $33 \%$ were taking analgesics for inappropriate reasons; and Grimlund (1963) could not find a single case of addiction among 189 factory workers, all of whom were misusing analgesics. Although psychiatric symptoms are a feature of chronic phenacetin overdosage (Schweingruber, 1955), most authors regard their patients as having a psychiatric instability which predisposes to the abuse.

The clinical picture of a secretive neurotic woman addicted to phenacetin is very different from our patient and we have been unable to find a counterpart in the literature. Many patients with ulcerative colitis are relieved if they can avoid being dependent on their doctors, especially if their treatment has involved unpleasant experiences. They may try to retain independence by obtaining their own drug supplies. Our patient was not told that compound codeine tablets were dangerous in spite of the recommendation of the Pharmaceutical Society of Great Britain (Anon., 1965). The simplest way to prevent misuse would be to dispense phenacetin-containing compounds only on prescription.

\section{Summary}

A case of phenacetin nephropathy is reported in a patient with an ileostomy, following a colectomy for ulcerative colitis. Renal damage occurred as an unwanted effect of the phenacetin content of compound codeine tablets, which were taken for the constipating action of their codeine component. It is hoped that the publication of this case may prevent similar occurrences.

\section{Acknowledgments}

We are grateful to Dr Kenneth Perry for permission to publish this case.

\section{References}

Abrahams, C., Wheatley, A., Rubinstein, A.H. \& Stables, D. (1964) Hepatocellular lipofuscin after excessive ingestion of analgesics. Lancet, ii, 621 .

ANon. (1965) Leading article. Phenacetin and the kidney. Brit. med. J. i, 673.

Burry, A.F., De Jersey, P. \& Weedon, D. (1966) Phenacetin and renal papillary necrosis: results of a prospective autopsy investigation. Med. J. Aust. i, 873.

Clausen, E. \& Pedersen, J. (1961) Necrosis of renal papillae in rheumatoid arthritis. Acta med. scand. 170, 631.

DaWBorN, J.K., Fairley, K.F., KinCaID-Smith, P. \& KING, W.E. (1966) The association of peptic ulceration, chronic renal disease and analgesic abuse. Quart. J. Med. 35, 69.

Grimlund, K. (1963) Phenacetin and renal damage at a Swedish factory. Acta med. scand. Suppl. 405, 1.

Gsell, O., Kielholz, P. \& HegG, J.J. (1961) Phenacetinabusus. Schweiz. med. Wschr. 91, 1529.

HaRVALD, B. (1963) Renal papillary necrosis: a survey of 66 cases. Amer. J. Med. 35, 481.

Jensen, E.J., Baggenstoss, A.H. \& Bargen, J.A. (1950) Renal lesions associated with chornic ulcerative colitis. Amer. J. med. Sci. 219, 281.

Kasanen, A., Forsström, J. \& Salmi, H.A. (1962) On the commonness, causes and detrimental effects of the use of analgesics by factory workers and hospital patients. Acta med. scand. 172, 15.

Kielholz, P. (1957) Abusus and Sucht mit phenacetinhaltigen Kombinationspraparaten. Schweiz. med. Wschr. 87, 1131 .

LARSEN, K. \& Moller, C.E. (1959) Renal lesion caused by abuse of phenacetin. Acta med. scand. 164, 53.

Moeschlin, S. (1958) Phenacetinabusus und Nierenschadigung (Ed. by H. Sarre), p. 53. Thieme, Stuttgart.

NoRdenfelt, O. \& RingerTZ, N. (1961) Phenacetin takers dead with renal failure. Acta med. scand. 170, 385.

PrescotT, L.E. (1966) Analgesic abuse and renal disease in North-East Scotland. Lancet, ii, 1143.

Reynolds, T.B. \& Edmondson, H.A. (1963) Chronic renal disease and heavy use of analgesics. J. Amer. med. Ass. 184, 435.

Rubinstein, A.H., Abrahams, C., Stables, D.P. \& Levin, N.W. (1964) Acetophenetidin nephritis and papillary necrosis. Arch. intern. Med. 113, 378.

Schweingruber, R. (1955) Probleme der chronischen Vergiftung mit kombinierten Phenacetinpraparaten. Schweiz. med. Wschr. 85, 1162.

SPUHLER, O. \& ZOLLINGER, H.U. (1953) Die chronischinterstitielle Nephritis. Z. klin. Med. 151, 1. 